\title{
Organisational reform and the extra-parliamentary party
}

\author{
Richard Kelly
}

As shown by the history of the Labour Party after 1979, electorally defeated parties have a tendency to re-examine their organisation. After all, the main function of political parties is to seek power and the main function of party organisation is to help them achieve it. As such, electoral failure nearly always brings into question a party's internal arrangements - and this was certainly true of the Conservatives after the 1997 general election. As Alan Clark MP noted, 'the Conservative Party is now like a defeated and invaded country, where the old power structures are shattered and the old currency useless'. ${ }^{1}$

\section{The lessons of 1997}

After the 1997 defeat, Conservatives were inclined to argue that faulty organisation - particularly in respect of their extra-parliamentary wings formed a key reason for the dismal showing. This is not to say they discounted their shortcomings in government or the advent of New Labour, but there was a clear sense that the enormity of the defeat could have been avoided had the party been organised differently. To support this thesis, Conservatives pointed to three factors which may have contributed to Labour's landslide.

\section{A LACK OF UNITY}

Between 1992 and 1997, the Conservative Party appeared chronically divided and 'at war with itself'. ${ }^{2}$ Much of this disunity came from ideological uncertainty, particularly over Europe. Yet the problem was exacerbated by the peculiar nature of the extra-parliamentary party. The great anomaly of the Conservative organisation, dating from its inception after the 1867 Reform Act, was the formal divide between the party's MPs and its volunteers outside Parliament. Far from being a tightly knit party, the Conservatives were a collection of three disparate organisations: the Conservative Party in Parliament, the National Union of Conservative Associations (the voluntary extra-parliamentary party), and Conservative Central Office (the professional 
or bureaucratic wing of the extra-parliamentary party). As an Inland Revenue report confirmed in 1982, 'the Conservative Party' did not even exist as a legally recognised entity. ${ }^{3}$

After 1992, this organisational fracture had damaging consequences for the party's electability. It meant, for example, that parliamentary leaders had scant power over the reselection of MPs as parliamentary candidates, the National Union's separate status giving constituency members huge autonomy in matters of candidate selection. As a result, Euro-sceptic MPs like Teresa Gorman, having secured the backing of their associations, could be persistently critical of the leadership without seriously endangering their future as MPs. ${ }^{4}$ This in turn diverted the loyalty of many Tory MPs; this in turn wounded party unity; this in turn gave an image of ineffectual leadership; this in turn cost votes.

This pitfall reappeared in the run-up to the 1997 general election. Anxious to contain the 'sleaze' factor, the leadership implored the Tatton association not to reselect Neil Hamilton as its candidate. Yet the association could not be compelled to do so, and chose to ignore the leadership's advice. The result was the loss of a safe Tory seat, and grave damage to the Tory cause. $^{5}$

\section{A LACK OF DEMOCRACY}

The second vote-losing aspect of Conservative organisation was thought to be a lack of overall democracy. The party's structure was still based upon an arrangement mapped out under Disraeli: one where the extra-parliamentary party would always be subservient to the parliamentary leadership. This arrangement conflicted with the decline of deference among Tory members after $1979 .{ }^{6}$ However, there were few concessions to party democracy during the Thatcher and Major governments. The party was supposedly 'reformed' and 'modernised' after 1992 via the twin reports of Sir Norman Fowler and Sir Basil Feldman. Yet the changes wrought were largely cosmetic, producing a 'Board of Management' whose functions were unclear, while confirming the primacy of the parliamentary leadership and the largely unelected nature of Conservative Central Office. ${ }^{7}$

That so little had changed was vividly demonstrated during the 1995 leadership contest. Whereas Labour sent out over 4 million ballot papers to all party members for its leadership contest in 1994, the Tories sent out only 329, the contest still being confined to MPs. To add insult to injury, local parties were 'consulted' by MPs, only for their advice to be frequently ignored. The Hazel Grove association, for example, gave unanimous support to the Prime Minister, yet its MP - Sir Tom Arnold - gave prominent backing to the challenger, John Redwood. ${ }^{8}$

The lack of influence accorded to the extra-parliamentary party, in such a high-profile area as leader selection, did not just foment division, it also 
strengthened the idea among voters that the party was elitist, insular, old fashioned, arrogant and corrupt - and thus meriting severe punishment in 1997.

\section{A LACK OF MEMBERS}

The lack of internal democracy contributed to the third vote-losing aspect of Tory organisation: falling membership. Across the democratic world, declining party membership is an almost inevitable consequence of socioeconomic change. Yet, with social deference in decline, it is even harder to recruit members if they are to be denied substantial influence. By 1997, even Tory activists felt that the party was 'still a feudal oligarchy, where power is concentrated in the leader's office'. ${ }^{9}$

Conservative membership looked in poor health and was said to be no higher than 400,000 in 1997.10 To make matters worse, a huge portion of members were passive and elderly. Holroyd-Doveton's study of the Young Conservatives, traditionally the most energetic wing of the party, claimed that membership had fallen from half a million in the 1950 s to about 8,000 by 1995, with Whiteley's team calculating in 1992 that the typical party member was sixty-two and fewer than 150,000 were 'active' in party business. ${ }^{11}$

In an age of voter volatility, a party's electoral prospects are easily harmed by such trends. Psephology showed that, with the demise of nationwide voting patterns, constituency campaigning was now often decisive, with a link unearthed between a party's vote in key marginal seats and the vigour of its campaign in the constituency concerned. ${ }^{12}$ Members also boost a constituency party's revenue, with studies showing that a party performs better in constituencies where it spends an 'above average' amount on local campaigns..$^{13}$

Long before the 1997 campaign started, the party recognised it would struggle with its constituency campaigns, especially in marginal seats where vigorous efforts were needed to counter anti-Tory tactical voting, and where since 1992 there had been a 30 per cent fall in the number of full-time constituency agents (professional organisers, traditionally employed to galvanise local campaigns). This gloomy assessment was later vindicated by the party's own pollsters, ICM, who claimed that 'low intensity' campaigns waged at constituency level led to the loss of up to eighty seats in 1997 - a staggering indictment of the party's membership and organisation.

\section{Organisational reform: a Bennite or Blairite model?}

In the aftermath of 1997, the party was apt to recognise that the structures of 1867 were redundant. The 1997 leadership contest (which again disenfranchised the extra-parliamentary membership) strengthened the momentum for change, with all five candidates promising greater unity and intra-party 
democracy. This consensus, however, merely begged a divisive question namely, in which order should these two goals be pursued? This may have seemed a bland question, but it was actually crucial to both the distribution of power inside the party and its chances of regaining support.

Had the Conservatives chosen to prioritise party democracy, they might have stumbled on to a path similar to the one Tony Benn charted for the Labour Party between 1979 and 1981 - one which relocated power within the extra-parliamentary ranks, created executive bodies that would be accountable to the extra-parliamentary party, and which sought 'unity' only within the context of member sovereignty; in short, a 'bottom-up' party no longer in thrall to its parliamentary representatives. ${ }^{14}$

However, if the party chose to prioritise 'unity' and managerial cohesion, it would have chosen the path down which Neil Kinnock and then Tony Blair directed Labour after 1983 - one which allowed party leaders and national officials to 'manage' the party more convincingly, which entrusted to those leaders and officials the quest for more members, and which extended party democracy only as a way of serving the leader's strategic goals. ${ }^{15}$ In other words, it involved the reinvention of a 'top-down' party that could achieve its aims more expediently and respectably, with the language of party democracy and OMOV ('one member one vote') cloaking the leader's steady accretion of power.

\section{A RADICAL PROPOSAL}

In the year leading up to the 1997 election, activists - already sensing defeat - had showed a growing interest in the quasi-Bennite option. Of particular interest was a proposal from the Party Reform Steering Committee (PSRC) - formed by a radical group of association chairmen in 1993 - which involved the abolition of the sprawling National Union, and its replacement by a single, yet pivotal, party committee that resembled Labour's National Executive Committee.

The committee PRSC wanted would have responsibility for all party matters outside Parliament, and would secure greater unity by harnessing senior parliamentarians to senior party activists. Yet it would also secure greater party democracy, and thus galvanise the membership, by ensuring that most committee members were voted in by, and accountable to, the constituency associations (only the leader and the Chairman of the MPs' 1922 Committee being ex officio). It was a bold idea with far-reaching implications; but it did not seem implausible given the coded support it received from the National Union Executive Committee, and its chairman Robin Hodgson.

\section{RADICALISM POSTPONED}

In the aftermath of the general election, however, the PRSC proposal was forgotten amid John Major's hasty resignation and the spiky leadership 
contest. This served to focus the party's mind on just one aspect of organisation - the mechanics of leader selection - while distracting it from deeper questions about power in the party. This has been corroborated by several constituency agents, one of whom recalled:

The leadership contest kept members interested in reform, but from then on they were preoccupied with just one area - the selection of party leaders and the battles they expected with MPs over who could vote in future. ${ }^{16}$

The membership's failure to see the 'wood for the trees' was to be deftly exploited by William Hague in the first year of his leadership.

\section{Hague’s hijack}

On 23 July 1997, Hague effectively hijacked the process of organisational reform. In a 'declaration' at Central Office, he announced that he would use the 'mandate' of his leadership victory to 'guide the party towards a fresh and more modern organisation'. ${ }^{17}$ The unilateral nature of this announcement was telling, as was his failure to make any mention of either the PRSC or the wider movement for reform inside the party. It suggested that, far from favouring 'root and branch democracy' (as he hinted days earlier), the new leader was taking the Kinnock-Blair road to reform, placing superficial unity above genuine democratic reform. ${ }^{18}$

Hague quickly set up an ad hoc committee, charged with producing a 'green paper' of reform proposals in time for the 1997 party conference. Its composition was instructive. Four of its five members were appointed by the new leader, with only one - Hodgson - being able to claim some elective link with the party membership. Surprisingly, there were few grass-root complaints about this; but the party's Charter Group (set up by Kent activists in 1981 to lobby for more party democracy) offers a worthy explanation:

The membership trusted their new young leader to get on with it ... having got the ball rolling in 1996, the grass-roots dropped it in 1997. It was then picked up by Hague and his henchmen who ran off with it in a completely different direction. ${ }^{19}$

To understand why members trusted Hague to 'get on with it', it should be recalled that Hague had cleverly distanced himself from the status quo by giving loud support to the OMOV principle for future leadership contests, an idea supported by most activists since 1992. ${ }^{20}$ Yet many Tory MPs like Archie Hamilton, chairman of the 1922 Committee, opposed it. This enabled Hague to posture as the grass-roots' champion: a doughty, state-school educated radical, confronting the parliamentary 'establishment'.

According to one of Hague's supporters, however, what the new leader really wanted all along was the 'New Labourfication' of the Conservative 
organisation, based on Hague's covert admiration for Labour's approach to opposition after 1994. ${ }^{21}$ Central to this strategy was new MP Archie Norman, former boss of Asda, a former colleague of Hague's at the McKinsey management consultancy, and one of Hague's most trusted confidantes in the first year of his leadership. According to another Tory MP, Hague envisaged Norman as:

A Tory Mandelson ... rooting out inefficiency in the party structure and turning it into a Millbank-style, vote-getting unit. The party would be rebuilt according to business management school principles, with the electorate seen as customers and membership as sales staff. ${ }^{22}$

This idea might well have wrought sweeping changes. But a significant extension of party democracy was unlikely to be among them.

\section{Coaxing the members}

'BACK ME OR SACK ME'

If, in terms of party management, there were similarities between Norman and Peter Mandelson, in terms of leadership techniques there were also similarities between Hague and Blair. An early illustration came with Hague's decision to organise an all-party ballot on his leadership, thus securing what Blair once called 'a licence from the whole party to drive the whole party'. ${ }^{23}$

To be held in the run-up to the 1997 conference, the ballot asked members to endorse both Hague and his 'six principles' of organisational change: 'unity, decentralisation, democracy, involvement, integrity, openness'. As there were no alternatives on offer, there was only a limited risk factor in Hague's 'back me or sack me' ballot. Nevertheless, among those who voted, almost a fifth rejected their new leader, with an apparent majority failing to vote at all (see Figure 5.1).

\section{BLUEPRINT FOR CHANGE}

Insisting that his authority was stiffened, Hague instructed his steering committee to finalise its green paper, Our Party: Blueprint for Change, before the close of the conference. Co-authored by Hodgson and new Party Chairman Lord Parkinson, its central suggestion reflected the main theme of the Party Reform Steering Committee, viz, the abolition of the National Union, and the creation of a 'single party' overseen by an all-powerful party board. Yet, unlike the PRSC, Blueprint for Change was hazy about the content of this committee, and the extent to which it should be elected by party members.

Any idea that the green paper might be assessed at the conference was blighted by the fact that its organisational debate was dominated by the issue of leadership elections - a subject with again drew the wrath of activists (encouraged by a populist speech from Lord Archer). It was accepted, 
I October 1997: Hague's leadership

Yes: 142,299 (80.7\%) No: 34,092 (19.3\%)

Ballot papers returned: $44 \%$

2 February 1998: The Fresh Future

Yes: 110,165 (96.1\%) No: 4,425 (3.9\%)

Ballot papers returned: 33\%

3 October 1998: Euro policy

Yes: 175,588 (84.8\%) No: 31,392 (15.2\%)

Ballot papers returned: $60 \%$

4 October 2000: Draft manifesto

Yes: 49,932 (98.8\%) No: 576 (1.2\%)

Ballot papers returned: $16 \%$

5 September 2001: Leadership contest

Kenneth Clarke: 100,864 (39.2\%) Iain Duncan Smith: 155,933 (60.7\%)

Ballot papers returned: $79 \%$

Figure 5.1 Conservative all-party ballots, 1997-2001

however, that Blueprint for Change would be discussed more thoroughly in the months that followed.

Parkinson organised twenty-six party 'road shows' between October and December 1997, where all interested members could express an opinion about the future shape of the party. Activists were aware that Blueprint for Change would form the genesis of a final set of proposals to be voted on - in another all-party ballot - the following spring. If successful, the proposals would then form the basis of a new Conservative Party Constitution.

Over 3,000 members attended the road shows, overseen by Parkinson's team from Central Office. Yet many seemed unhappy with the format. According to one association chairman:

All we were allowed to do was discuss their proposals and their ideas. They [the Parkinson team] weren't really interested in any initiatives we might have had, and it was made clear that they would be the ones who drew up the final proposals. ${ }^{24}$

THE FRESH FUTURE

The final proposals were indeed drawn up by Parkinson, Hodgson and Hamilton and collated into a 'white paper', entitled The Fresh Future and published in February 1998. When comparing The Fresh Future with Blueprint for Change, there were few signs that membership input made much difference during Parkinson's road shows. This was noticeable in relation to the 
replacement of the National Union by a new Party Board, the centrepiece of the proposed party constitution (see Appendix p. 103).

One of the most important suggestions of Blueprint for Change was that 'about half of the Board should be elected and half appointed by the Leader, including the Party Chairman'. When compared to the PRSC idea, this represented a clear dilution of party democracy; it is perhaps unsurprising that only 50 per cent of respondents expressed agreement, with almost a third disagreeing strongly. ${ }^{25}$

Yet, with breathtaking chutzpah, the authors of The Fresh Future went on to dilute even further the Board's democratic content, proposing that only five of its seventeen officers should be elected by the membership. Even these would be elected not by the whole membership, but by the 1,000-odd senior officials on the new National Convention (see Appendix p. 103). Indeed, nine of the Board's members would have no elective connection at all to the constituency membership. Any grass-root dissent, however, was to be quelled by a suspiciously timely development at Westminster.

Just weeks before the ballot was due, it was announced that MPs had relented on the issue of leadership selection, accepting OMOV as opposed to their initial compromise idea of an electoral college. By the time members came to vote on The Fresh Future (which would now incorporate the MPs' volte face) talk in the party was dominated by what journalists called 'the MPs' surrender' and the 'triumph of the activists' - effectively distracting attention from the Board's undemocratic tendencies. ${ }^{26}$ All this made the clear 'yes' vote barely surprising, although the low turnout prompted the Charter Movement to contest the legitimacy of the reforms (see Figure 5.1).

When reflecting on the birth of The Fresh Future, the parallels with New Labour party management are almost eerie - particularly in respect of Labour's Clause IV debate of 1994-95. There too was a tightly managed 'consultation' period, with members only allowed to discuss proposals drawn up by the leadership. There too was an all-party ballot to validate change. There too, members could merely ratify or reject the package on offer. And, there too, a new party leader claimed democratic backing for a reform which arguably cheated party democracy. ${ }^{27}$

\section{Fresh Future, fresh oligarchy: the erosion of local autonomy}

The associations had very limited control over the new Board's composition. This was a serious, democratic failure given its new and extensive powers over them. Three particular areas of Board jurisdiction suggested that, under the new 'single party' arrangement, the associations had surrendered their former autonomy to the new Party Board, which then granted them responsibility without power. Put simply, members were accountable to this new centralised committee, yet had little influence upon it. 
The first of these areas stems from a sub-unit of the Board known as the Ethics and Integrity Committee (EIC), comprising just four people: two QCs appointed by the Party Chairman, the Chairman of the 1922 Committee and the Chairman of the National Convention. It was empowered to act "whenever the reputation of our party is threatened' by the associations, their chosen candidates or indeed any other party member. According to Article 81 of the new Constitution, the EIC was able to suspend or expel 'any individual who brings the party into disrepute'. ${ }^{28}$

In the mind of most activists, the EIC was set up to prevent any more Tatton-style scenarios, where the party was damaged by a candidate seemingly short of personal integrity. Its work in the Hague era bears out this impression - its most serious task being the investigation, and then suspension, of Lord Archer in February 2000, amid police inquiries into the peer's libel case of 1987. However, 'disrepute' is a loaded term and it might yet be used to debar the reselection of rebellious MPs. If so, the national party bureaucracy has quietly gained more control over both backbenchers and constituency parties: a clear echo of the centralising trends within the Labour Party after 1989. ${ }^{29}$

The second area where associations have been compromised concerns the Board's 'efficiency criteria', a set of standards laid down by the Board which govern the everyday conduct of constituency parties. ${ }^{30}$ If these are not met, the Board can step in to reorganise an association, sack its officials and temporarily assume command of its affairs - very similar to what happened in the Labour Party under Kinnock when a string of constituency parties where purged and reformed by national apparatchiks.

The third area concerns the power that national officials may now have to plunder association funds. Although Central Office has been in almost constant debt since 1983, certain associations (like Aylesbury and Hampshire East) are legendarily flush, their surpluses protected by the associations' historic autonomy. However, under the new Constitution, associations are obliged to give the Board annual details of their accounts and, when allied to the 'single party' ethos, this could lead to the Board raiding local party funds in search of central party solvency. As a result, the associations' financial independence, once a vital check upon oligarchic rule within the party, has been discreetly weakened.

\section{The Norman conquest: a reformed Central Office}

If the new Board gave constituency members greater responsibility without much extra power, it also gave certain national officials greater power without much extra responsibility. Archie Norman was a prime example of this development. Norman was the new leader's organisational guru Hague firmly believing that the managerial principles which revived Asda 
supermarkets could also revitalise the Conservative Party. Norman was appointed to the new position of Chief Executive in July 1998, his brief being to 'overhaul and modernise Conservative Central Office'. ${ }^{31}$ It is telling that the appointment was made unilaterally by Hague, clearly unencumbered by the Party Board, the National Convention, or indeed any of the 'democratising' party bodies created by the 1998 reforms.

Norman set about a 'rationalisation' of Central Office (CCO) which involved a $£ 3$ million cut in spending, redundancy for 40 per cent of the staff, plus the closure of several regional offices. Those sacked included former campaigns manager Tony Garrett, an official who had worked with the party for twenty-seven years and who had nurtured a large network of useful allies at association level - many of whom were 'outraged' by his departure. ${ }^{32}$

Norman's rationalisation was made more provocative by the management consultant he brought in to assist him: Peter Samuel, someone with impeccable managerial credentials, but also chairman of the Reigate Liberal Democrats and their candidate at the 1997 general election. As one association chairman commented:

It is bad enough that a man who spends his leisure time fighting our party should be given access to our national office. But it is incredible that he should be paid, out of party funds, to effectively sack loyal servants of the Conservative Party. ${ }^{33}$

The outcome of the Norman-Samuel 'revolution' was what Norman billed a 'World Class Political Centre', unveiled in August 1998 (see Figure 5.2). Plagiarising Labour's Millbank headquarters, it gave CCO a 'war room' format that would grant huge leverage to its Research and Communications Directors, notably Danny Finkelstein and Amanda Platell. Again, such key officials were to be appointed by either Hague or Norman, rather than elected by the membership.

Norman also reshaped two other areas of $\mathrm{CCO}$ activity without much regard for party democracy.

FINANCE

The new Income Generation and Marketing Department was to be run, like the old Treasurer's Department, by an appointed party Treasurer - the unelected status of the party's chief fund-raiser being a particular gripe of the Charter Movement and PRSC. It might have been thought that, with the impending Neill report on party funding (limiting national campaign spending and individual donations), the new Department's focus would eschew plutocratic donations for more constituency-based fund-raising.

In fact, the opposite occurred, party fund-raising after 1997 becoming even more synonymous with a handful of wealthy contributors. ${ }^{34}$ Tycoon Michael Ashcroft was appointed Treasurer in 1998, largely because his own 


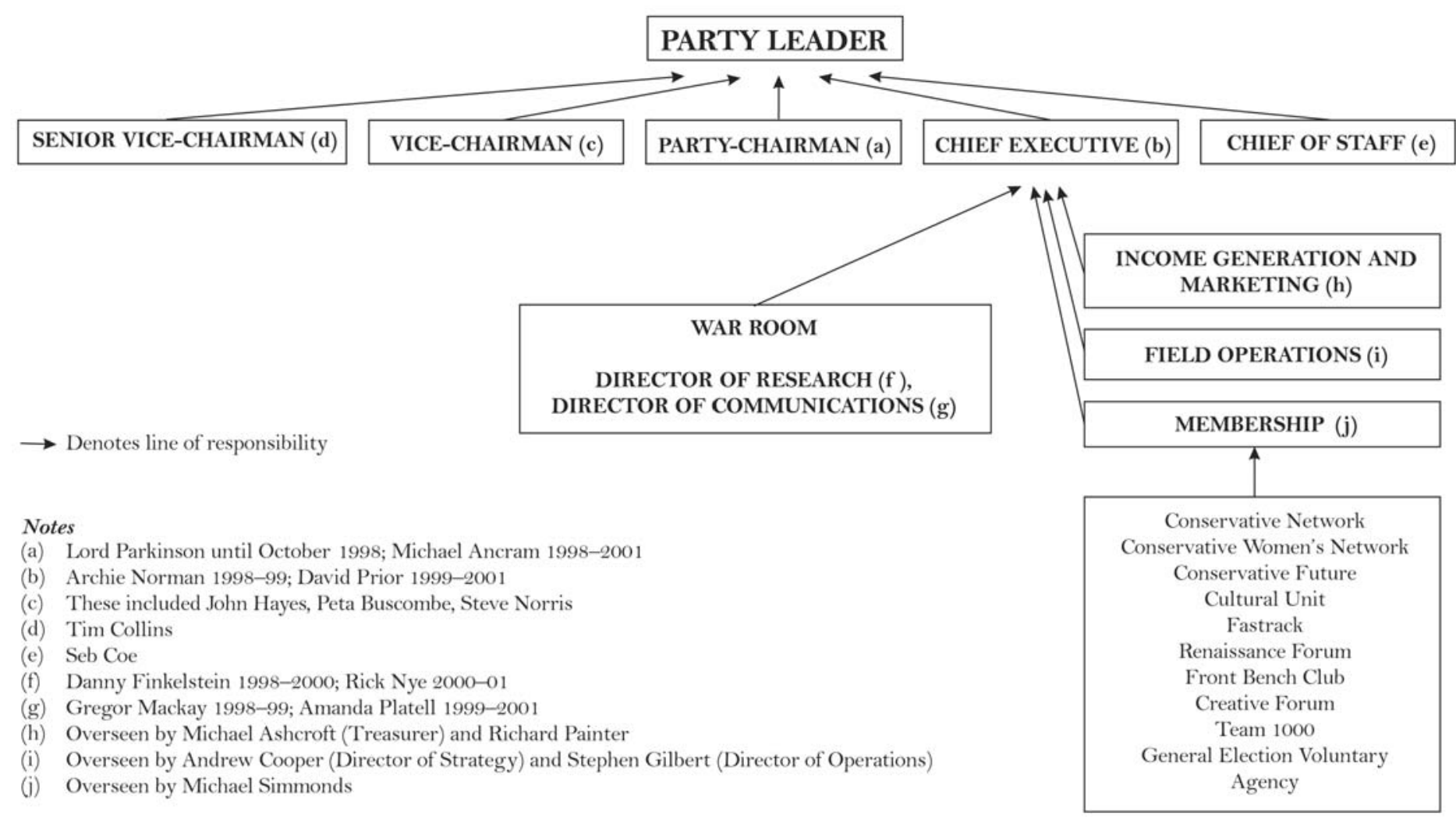

Figure 5.2 Conservative Central Office, 1998-2001

Sources: Archie Norman, MPMO, 14 July 1998; Chris Poole (Secretary, National Convention) letter, 13 June 2001. 
donations had 'kept the party going' since 1997..5 Accounts published in October 2000 showed that Ashcroft was bankrolling the party to the tune of over $£ 1$ million a year, making his total contributions since 1997 well over $\mathscr{L}^{4}$ million. ${ }^{36}$ Ashcroft's main impact seemed to be in increasing the number of individuals donating over $£ 5$,000 - from thirty-three in 1997-98 to 126 in 1999-2000. Donated income increased to $£ 7.2$ million (the $£ 5$ million promised for the 2001 election by Stuart Wheeler, of the IGIndex spreadbetting company, proved especially newsworthy). To Ashcroft's credit, these gifts helped convert a CCO deficit of $£ 8$ million in 1997 to a surplus of $£ 4,000$ in 2000.

Ashcroft's financial strategy, however, did little to alter the oligarchic nature of power inside the Conservative Party. Having had so little influence over the raising of revenue, activists could do little but complain about dubious expenditure sanctioned by national officials. The 'Listening to Britain' exercise, which ran between July 1998 and July 1999 (see below), cost over $£ 250,000$. Yet neither the idea nor its execution was seriously considered by the bulk of party members. ${ }^{37}$

\section{MEMBERSHIP RECRUITMENT}

Norman's new Membership and Constituency Services Section was also undemocratically structured and did little to empower constituency members. On becoming leader, Hague had committed himself to expanding the membership to almost a million, with at least half the new members being under thirty-five. However, as with Labour's national membership scheme of the late 1980s, this task was not to be entrusted to existing constituency members. Instead, the task was assigned to a host of unelected - and, to most members, oblique - agencies within CCO's Membership section, all trying to recruit members centrally.

Simply because of their sheer number (see Figure 5.2), it was inevitable that these agencies would overlap and waste party resources in the process. 'Conservative Network', found itself targeting the same 'young professionals' as the new 'Fastrack' outfit, while those running the 'Renaissance Forum' (aimed at 'energetic entrepreneurs') often collided with those from 'Team $1000{ }^{38}$

Despite some slick advertising, these new central bodies had limited impact. The 'Conservative Women's Network', set up to recruit 'high flying professional women', was described in 2001 (by its outgoing chief Peta Buscombe) as a 'depressing failure', with women under forty-five representing just 2 per cent of the membership. ${ }^{39}$ It is also striking that the number of ballot papers sent out for the 2001 leadership race (about 318,000) was significantly less than that sent out for the first all-party ballot of 1997 $(399,203)$. This may simply suggest that by 2001 the party had a more realistic view of its membership figures. But it also suggests that, far from 
rising to the giddy heights predicted by Hague in 1997, membership may have fallen by about a fifth during his leadership.

\section{NORMAN'S LEGACY}

Norman's tenure as 'chief executive' ended in the summer of 1999. His claim that the party bureaucracy had been 'streamlined' merits intense scepticism. As Figure 5.2 reveals, it merely produced a labyrinthine structure that lacked any obvious chain of command. The question of who was primus inter paresParty Chairman or Chief Executive - was never resolved; the issue of whether the Senior Vice Chairman (Tim Collins) was primarily responsible to the leader or Party Chairman remained unclear; while the status of Seb Coe (Chief of Staff and one of Hague's most trusted advisors) was problematic for many CCO staffers. By $2001 \mathrm{CCO}$ was in a state of 'internecine confusion', prompting quips that Norman brought about the 'Asdastruction' of party headquarters. ${ }^{40}$

There was little evidence of the 'democratic revolution' promised by Hague in July 1997. The associations' influence upon CCO was unenlarged, while (thanks to the new Board) CCO's influence upon the associations was extended. Although the structures might have been 'fresh', the locus of power was decidedly stale.

\section{Concessions to democracy?}

In view of what has been written so far, it is strange to recall Hague's insistence that he had 'democratised' the party. To make sense of this, it must be conceded that, in three corners of the party organisation, there was some evidence of OMOV principles being applied - these being policy formation, candidate selection and leadership selection. Yet the key point about these changes is their origin: most came not from a democratised command structure (which, as we have seen, was not a feature of the 1998 reforms), but from a reformed oligarchy that occasionally trusted the membership. Furthermore, in all three areas, the democratic element was diluted in the interests of centralised party management.

\section{POLICY FORMATION}

According to the leadership, the democratisation of policy took two forms. First, Hague's leadership saw the advent of all-party ballots not just on organisational matters but on policy matters too. The first example of this came in the autumn of 1998, when the party was balloted on the leadership's tougher stance on the European single currency (see Figure 5.1).

Although 85 per cent of voters endorsed Hague's policy, far from giving members a rational choice about European policy, the ballot was presented as yet another vote of confidence in the leadership (in which case the 'No's' and abstainers represented an alarming number of anti-Hague members). It 
was widely recognised within the party that by ordering the ballot, Hague was not simply driven by a desire for party democracy; he also saw it as an effective way of binding the party to his chosen European policy and silencing its critics within the party (again redolent of Blair's Labour Party ballots on Clause IV and the 1997 manifesto).

The second all-party ballot on policy came at the end of 2000, when members were asked to endorse the leadership's draft manifesto, Believing in Britain. As with Labour's manifesto ballot of 1996, members were not given the chance to approve or reject specific items; they could either take it or leave it. According to the party's own figures, over four-fifths chose to leave it - the overwhelming 'yes' vote being less important than the fact that so few members took part (see Figure 5.1).

When questioned about the 'take it or leave it' aspect of the manifesto ballot, Central Office officials conceded that the draft had been mainly constructed by the leader's 'A-Team' of senior MPs and advisors: Hague, Lansley, Finkelstein, Michael Portillo, Ann Widdecombe and Francis Maude. Yet it was stressed that that there had been 'an unusually wide' degree of consultation beforehand, particularly during the 'Listening to Britain' exercise of $1998-99 .^{41}$

'Listening to Britain' involved over 1,400 meetings open to the general public and had various offshoots - such as the 200 or so 'Listening to Britain's Churches' meetings that apparently shaped the leader's strong support for marriage. This type of consultation was later complemented by a 'Common Sense Revolution' page on the party's web site: a cybernetic focus group, where browsers were invited to write in two 'common sense suggestions'. Here again, the large number of 'hits' concerning law and order and asylum were said to have affected the details of Believing in Britain. ${ }^{42}$ Yet the main point about this consultation was that, like New Labour's addiction to focus groups, it short-circuited party members.

In this respect, 'Listening to Britain' represented a vital change in the ethos of the Conservative Party, one which weakened further the autonomy and discretion of its constituency bodies. Even ten years earlier, policy consultation within the party had been quite member-oriented. During the 1980s, and for much of the twentieth century, the Conservative Party's 'conference system' had been a trusted conduit for electorally beneficial advice: the leadership trusting speakers from 'the floor' to transmit voters' opinions, as gleaned by their associations, to those sitting on the platform. ${ }^{43}$ This system was judged obsolete by 1997, with 'Listening to Britain' seen as a more direct and effective method of connecting voters to Tory policy makers.

Constituency members were not altogether excluded from this process; but in so far as they were involved, it was simply a case of them carrying out centrally devised procedures (as contained in the Listening to Britain 
I Conservative Policy Forum General Council commission 'outline documents' from policy specialists

2 Documents sent out to associations

3 Associations form policy forums to discuss documents. Reports sent back to $\mathrm{CPF}$ Director

4 Director passes reports to relevant shadow cabinet minister(s)

5 Shadow Cabinet minister or Director replies to associations

6 Associations may debate replies and send subsequent report to Director

7 Shadow cabinet ministers absorb forum reports into speech at main party conference

8 Conference acclaims minister $=$ 'good conference' for party managers.

\section{Figure 5.3 The Policy Forum system}

Source: R. Kelly, 'Farewell Conference, Hello Forum', Political Quarterly, 72:3 (2001).

Constituency Manual) before passing back the results, verbatim, to Central Office officials. As Andrew Lansley, its Director, commented: 'The rationale was to get in touch with the electorate, to extend our regular contact beyond members (italics added) ... and to change the culture of the party.' ${ }^{44}$

There was, however, still some opportunity for members-only contributions to detailed policy development, principally via the 'policy forums' set up under The Fresh Future (see Figure 5.3). These forums replicated an idea first outlined in Labour's 1997 Partnership in Power document and, as with Labour's own forums, were a response to the supposed failings of the party conference.

After 1997, the establishments of both parties claimed that the party conference did not allow ordinary members to make detailed contributions to policy discussion, and that constituency-based forums were a better mechanism for assimilating grass-root policy ideas. However, it is reasonable to assume that both party hierarchies were also worried about the damaging publicity wrought by stormy conference debates.

From the late 1980s onwards, Tory conferences seemed potentially more explosive than Labour's, as members threw off sycophancy in favour of frank criticism. The 1997 conference showed that this trend had not been abated by opposition; indeed, activists queued up to attack the competence and integrity of the parliamentary party. ${ }^{45}$ Consequently, the new leadership was keen to remodel Tory conferences with an eye to those of New Labour: relatively supine affairs, where criticism was often defused by imminent reports from policy forums.

In fairness to the forum system, over 5,000 constituency members were 
enthused enough to take part between 1999 and 2000, producing over 400 reports on assorted policy issues. In addition, participants often claimed a link between their conclusions and the details of Believing in Britain. One example of this came with marriage tax allowance (abolished by Labour in 1999). Hague had initially called for straightforward restoration. Yet, during their discussions of August 2000, forum members showed a surprisingly modern view of marriage and 'lifestyle', with a majority favouring an allowance which only rewards married couples with young children. Three months later, the leadership's own position was softened. ${ }^{46}$

It is interesting that, when explaining its U-turn, the leadership did not acknowledge the membership's influence, claiming instead that the change arose from the Shadow Cabinet's working party. Activists were being gently reminded that, despite their trumpeted role in The Fresh Future, the forums could only offer 'advice' on policy, which the leadership was free to disregard. Indeed, the party's U-turn on both the minimum wage and the independence of the Bank of England (accepting both) stemmed not from policy forums, or any consultation with the extra-parliamentary party, but from an inner circle within the Shadow Cabinet; activists being told, fait accompli, at the end of 1999.

\section{CANDIDATE SELECTION}

In the selection of Conservative candidates for Westminster, European and regional elections, The Fresh Future was keen to uphold the OMOV doctrine. Between 1997 and 2001, the Tories were not associated with some of the dubious practises seen in the selection of Labour candidates (the arrival in $\mathrm{St}$ Helens South of the Tories' former Communications Director, Shaun Woodward, being the most reported example).

By contrast, the Tories' procedures seemed refreshingly open and inclusive, the selection of Westminster candidates coming from a short-list of three to five candidates at a general association meeting which enfranchised all members. Kensington and Chelsea in 1999, which selected Michael Portillo at a general meeting attended by over 800 members. The principle of selecting at 'open-to-all' general meetings was also observed in the selection of Boris Johnson (Henley) and Paul Goodman (Wycombe).

Party democracy also seemed to have advanced in the selection of European Parliamentary candidates in 1999, competing for the first time under proportional representation (PR). In each of the 'areas' created by the PR system, every party member was entitled to attend a Final Selection Meeting to both choose and grade a list of Tory candidates; in the South East area, this involved over 1,500 turning up at the London Docklands arena which had been hired for the occasion. In the process of selection, it was also clear that (unlike in the Labour Party) prominent individuals were not being 'shoehorned' into safe positions: only four out of 120 interested ex-MPs 
gained a winnable place, with the rejected including loyalists like Tony Newton and dissidents like Norman Lamont. ${ }^{47}$

The party also emerged with some credit from the selection of candidates for the Scottish Parliament and Welsh and Greater London Assemblies (elected under the Additional Member System of PR), selecting both constituency and regional candidates through meetings open to all members, and again avoiding the charge that senior candidates were guaranteed prime positions, a charge that dogged Labour's Alun Michael in Wales. When selecting the mayoral candidate in Greater London, the party also conducted OMOV postal ballots open to all Greater London members, first selecting Lord Archer over Steve Norris and then, in a 'replay', Norris over Andrew Boff. On both occasions, the postal vote was preceded by a hustings open to all party members, which then voted on the final two candidates.

Although candidate selection afforded a large degree of influence to ordinary members, The Fresh Future cemented centrally controlled 'approved lists' of candidates. Apart from those seeking election to local councils, all would-be candidates had to appear on these lists before seeking nomination; and the lists' gatekeepers remained a party vice-chairman appointed by the leader and a clutch of anonymous Central Office officials.

Constituency autonomy was also threatened by the new Ethics and Integrity Committee and its 'efficiency criteria' for the associations, both of which gave national officials a potential veto over local selections. In the years ahead, this potential might well be exploited by a party hierarchy desperate to offer an electable brand of Conservatism, with matching candidates. Here again, New Labour could be an inspiration, Millbank having blocked a series of 'unsound' candidates while in opposition. ${ }^{48}$

\section{LEADERSHIP SELECTION}

For many students of party organisation, and for many in the Conservative Party, the 'democratisation' of Tory leadership elections was the defining feature of The Fresh Future. Disillusioned by the conduct of Tory MPs during the Major government, and scandalised by their monopoly of the 1997 leadership contest, the associations had demanded a clearer say in choosing party leaders. But the grass-roots' obsession with leadership selection came at a price - an erosion of democracy within the party overall.

Nevertheless, following The Fresh Future's reform of leader elections, Hague claimed a huge advance for grass-root power. There would be no Labour-style electoral college, where some votes carried more weight than others: the new Conservative system would allow its leadership contests to be decided by a pure, OMOV ballot where the vote of an ordinary constituency member was equal to that of a frontbench MP. However, the grass-roots would only get a choice of two candidates - the number having been whittled down by a series of 'quality control' ballots confined to MPs. 
The new system was given its first outing following Hague's sudden resignation after the 2001 election. As this was the first Tory leadership contest to enfranchise constituency members, it was always going to be a remarkable contest. Nevertheless, a number of telling points were to emerge about the new system and the state of the party generally.

Firstly, the 'either-or' nature of the final, OMOV ballot was a serious dilution of party democracy, and elicited many complaints from members keen on a wider choice. ${ }^{49}$ Indeed, polls suggested that many members, if forced to accept a choice of just two, wanted one involving Iain Duncan Smith and David Davis (the latter being excluded following the second ballot of MPs). These polls also showed considerable anger that one of the two final candidates was Kenneth Clarke, whose views on Europe made him 'an impossible option' for many members unsure about Duncan Smith. ${ }^{50}$

Secondly, following the final MPs-only ballot, party authorities came under pressure (notably from supporters of Portillo) to widen the choice available to members. Only one vote, after all, came between Duncan Smith (who came second) and Portillo (who was eliminated); indeed, only six votes stood between Portillo and Clarke, who topped the final MPs' poll. However, Sir Michael Spicer, chairman of the 1922 Committee, defended the either-or system on the grounds that more candidates might 'diminish the winner's share of the vote', a weak argument given the existence of electoral systems such as that used to elect the Greater London mayor. ${ }^{51}$ Had the result of the OMOV ballot been close, the party could have finished with the worst of all worlds - namely, a limited choice for members, which then produced a winner with only the barest of mandates.

Thirdly, despite Clarke's emergence in the final round, there were signs that grass-root opinion influenced the votes of several MPs during the preliminary ballots. Portillo's failure to build up support in the second and third rounds of the parliamentary ballots was apparently affected by the negative vibes many MPs detected about him from their associations. ${ }^{52}$ This covert extension of party democracy, however, has to be tempered by the fact that in 476 associations, there was no Tory MP through whom members could transmit their opinions; neither was there any alternative channel provided by the party. As Tories in seatless areas like Liverpool remarked: in terms of which two candidates we could choose from, our opinions counted for absolutely nothing' ${ }^{53}$

A fourth point is that the OMOV ballot was given added importance by the fragmented support of Tory MPs. In the first parliamentary ballot, not one of the five candidates polled even a third of the votes, while in the final ballot no candidate came close to achieving a majority. As such, the membership's choice was unaffected by any clear preference on the part of Tory MPs: the extent to which members could be affected by MPs' preferences thus remains unclear. 
Fifthly, thanks to the all-party finale, Duncan Smith was able to win the leadership without having won the backing of even a plurality, let alone majority, of his own MPs (Portillo and then Clarke topping the MPs-only elections). Even in the final ballot, barely a third of Tory MPs backed the man who, two months later, became their leader. It remains to be seen how this anomaly will affect Duncan Smith's authority within the parliamentary party. Although he is not the first leader of a major party to be elected by extra-parliamentary members, he is the first to be elected without being the clear favourite among a party's MPs (Kinnock, Smith and Blair all had substantial leads within the MPs' section of Labour's electoral college). Duncan Smith is in uncharted waters as far as modern party leadership is concerned, and it may prove difficult for him to assert discipline over recalcitrant Tory MPs.

Sixthly, the final result, announced on 13 September, suggests that the Conservative Party has even fewer members than previously supposed. ${ }^{54} \mathrm{CCO}$ had sent out 318,000 ballot papers via the constituency associations (stating that only those who had joined before 28 March could vote). According to $\mathrm{CCO}, 20$ per cent of members 'abstained'. Yet, given that turnout in the four preceding party ballots never exceeded 207,050 (see Figure 5.1), it is reasonable to assume that those who voted in 2001 were practically the whole Conservative membership. Ergo, the party may well have fewer than 260,000 members.

The contest also highlighted the mysterious nature of Conservative membership. With the party's national membership scheme being set up in 1998, only about 33,000 members could be identified by party headquarters. Even John Barnes, an academic authority on the party and active constituency member, knew 'next to nothing' about the bulk of members in his own association, claiming that only about 5 per cent were ever seen. ${ }^{55}$ Efforts to find out more were hampered by the Data Protection Act and its rigid enforcement by CCO's acting chief executive, David Prior. The two final candidates could not contact members directly, and had to rely on each association distributing their A4-size manifestos to members. As the Daily Telegraph remarked this was 'the first election in the history of the world where contenders are unable to know who their electorate is'. ${ }^{56}$

Polls carried out during the contest supported Whiteley et al.'s findings, by indicating that about 80 per cent of members were over sixty. But these polls also showed that the membership had become much more exercised by the European issue and more Euro-sceptic as a result - underlined by Clarke's heavy defeat. They also showed that only a third of members accepted the case for 'radical change' within the party: a factor in their hostility to Portillo. ${ }^{57}$

Finally, the OMOV contest highlighted the limited role of the National Convention, billed by The Fresh Future as a pivotal body for extraparliamentary members (see Appendix p. 103). During the contest, it 
convened only once for a two hour hustings, with attendance circumscribed by its mid-week, afternoon scheduling. Of far more importance were the eight hustings organised across the country during August, which attracted about 5,300 activists. ${ }^{58}$

\section{CHALLENGING THE LEADER}

Owing to Hague's voluntary departure, we are yet to gauge fully The Fresh Future's effect upon challenging an incumbent leader. However, both the 1998 rules and the 2001 contest point to a clear limit upon intra-party democracy. The rules state that a vote of confidence can only be sparked by a petition signed by 15 per cent of MPs, that only MPs can vote, that a mere 51 per cent voting 'No' means the leader has lost, and - crucially - that such a leader cannot be a candidate in a subsequent contest. This means that a leader who has won overwhelming support from the grass-roots could still be ousted by a numerically small fraction of party members (just eighty-four MPs according to 2001 figures). Given Duncan Smith's limited support in the MPs-only ballots of 2001, such a scenario is not implausible and was highlighted by the refusal of several prominent MPs (including Clarke, Portillo, Maude, Widdecombe and Norman) to serve in his Shadow Cabinet.

On the other hand, Duncan Smith might be secured by the new and tortuous process of finding a replacement. As we saw in 2001, leadership contests which go beyond Westminster take far longer to complete: whereas it took the Tories less than three weeks to oust and replace Margaret Thatcher, it took them over three months to find a successor to Hague. Subsequently, there may be strong incentives to leave an incumbent alone, as a drawn-out challenge (especially one as acrimonious as the Clarke/Duncan Smith battle) could damage the party even more than the continuation of a lacklustre leader. This calculation that probably saved Kinnock's leadership of the Labour Party between 1990 and 1992, eclipsing the Parliamentary Labour Party's fear that he was an electoral liability. ${ }^{59}$ All this suggests that swift and ruthless changes of leadership - a recurrent feature of Tory history - are now less likely thanks to The Fresh Future. Far from making future Tory leaders more 'accountable', as Hague suggested, the reform may have simply made them more comfortable.

By the end of 2001, there was a widespread belief inside the party that the 1998 leadership rules would not even survive their first try-out. At the 2001 party conference, the Campaign for Conservative Democracy (led by John Strafford) spearheaded demands for a shorter contest which gave constituency members a wider choice of candidates - an idea supported by several MPs, such as Andrew Tyrie. New Party Chairman, David Davis, accepted the need for 'review and fine-tuning', despite ruling out any 'complete overhaul' of procedures. ${ }^{60}$ 


\section{Conclusion: new defeat, old lessons}

The 1997 defeat undermined Conservatives' faith in their old organisation. Strangely, the party's equally poor showing in 2001 did not ignite similar criticism of their new one. As in 1997, no one seriously argues that the Tories lost because of poor organisation. Yet, when surveying the size of the defeat, and the fact the party made virtually no progress since 1997, we can again argue that flawed organisation was a contributory factor. Although the party looked more cohesive in 2001 than it did in 1997, behind the glossy exterior lay serious organisational problems - problems which were either ignored, or caused, by The Fresh Future.

Reflecting on the 2001 defeat, one constituency agent described the Tories' campaign as akin 'to an army which over-relies on heroic officers' ${ }^{61}$ The campaign was heavily centralised, depending to a large extent on the physical stamina of Hague, who covered more miles during a general election campaign than any previous Tory leader. Yet the leader was conspicuously short of foot soldiers in the constituencies he visited.

Most of us who observed the Tories' local campaigns in 2001 would affirm the party's reputation for an ageing, dwindling and inactive membership. Given the importance of constituency campaigning, we might conclude that, as in 1997, the Tories' weak constituency campaigns in 2001 were a crucial reason for the defeat in most target seats. Inter alia, this strongly suggests that the reorganisation of 1998 was either irrelevant or ineffective, a new defeat simply highlighting old problems.

As Hague himself argued when he became leader, to get more votes the party needed more members; to get more members it needed more democracy; and to get more democracy it needed to decentralise. Yet, The Fresh Future lost sight of this basic thesis and chose instead to ape the centralising trends of the Labour Party - overlooking studies which showed that these trends retarded Labour's prospects at the 1987 and 1992 elections, and were only exonerated in 1997 after a disastrous period of Tory government. ${ }^{62}$

It is true that the language of OMOV was heard inside the Tory Party after 1997, and that this sometimes led (as with candidate selection) to greater empowerment of ordinary members. But, as with New Labour, the leadership's use of OMOV was less a sign of thoroughbred democracy than of short-term party management, helping to stifle the leader's critics within the parliamentary party while making the party look more 'modern' and 'inclusive'. ${ }^{63}$

The axis of the 1998 reform was not OMOV, but an overarching Party Board with only limited democratic input. Its existence was to nourish the party's top-down mentality, stifle grass-root initiatives, sanction the unaccountable power of people like Archie Norman, dupe senior MPs into thinking that, by dealing with this Board and its various committees, they were dealing 
with 'the party', and stall a reform process which, in terms of exalting (and thus attracting) constituency members, still had a long way to go by 1998 .

Consequently, by 2001 the party was still languid outside its central headquarters. The party's Area Campaign Directors were left to cover thirty to forty seats each, instead of the ten to twenty which most of them see as conducive to efficiency; the Area Research Departments had all but vanished, leaving many candidates unsure about the constituencies they were contesting; and party organisation was almost non-existent in major cities other than London - partly accounting for the Tories' failure to come even second in any Manchester or Liverpool constituency.

The result of this regional atrophy, and the loss of members that went with it, was obvious during the 2001 campaign: an impossible burden placed upon the leader and his elite corps. As his resignation showed, this burden took a heavy toll upon Hague. But it was one his own reforms invited.

\section{Appendix: Fresh Future, fresh structures}

THE BOARD

The Board meets once a month and has ultimate responsibility for all aspects of party management outside Parliament. In September 2001, its composition was as follows:

David Davis (Party Chairman)+

John Taylor (Chairman of National Convention)*

David Prior (Deputy Party Chairman and CCO Chief Executive)+

Lord Ashcroft (Chairman, Board of Treasurers)+

Jean Searle (President, National Convention)*

Richard Stephenson (Vice-President, National Convention)*

Don Porter (President, National Convention)*

Caroline Abel-Smith (Vice-President, National Convention)*

Sir Michael Spicer (Chairman of 1922 Committee)+

Lord Hanningfield (Chairman, Conservative Councillors' Association)

Lord Strathclyde (Party leader in House of Lords)+

Bill Walker (Deputy Chairman, Scottish Party)

Henri Lloyd-Davies (Chairman, Welsh Party)

Stephen Gilbert (Director, Field Operations CCO)+

Edward Macmillan-Scott (Leader of Conservative MEPs)+

Lord Trefgarne (Chairman, Association of Conservative Peers)+

Chris Poole (Secretary to the Board - but no vote)+

THE NATIONAL CONVENTION

This is the representative body of the voluntary party and is the successor to the National Union. Comprising about 1000 officials, it meets twice a year: once at its Spring Conference, where its officers and representative on the 
Party Board are elected, and again at the main party conference. It is supported by a network of 11 regional councils and 42 area councils. Its membership comprises:

The Chairman of every constituency association

Its Chairman, 2 Presidents, and 2 Vice-Presidents

(who also serve as its representatives on the Board)

Members of Area Management Executives

Regional Co-ordinating Chairmen and their deputies

Representatives of party's youth, women and other recognised organisations

Its 3 immediate past Presidents

Its 2 immediate past Chairmen

The immediate past Area Chairmen

The immediate past Regional Co-ordinating Chairmen

THE NATIONAL CONVENTION EXECUTIVE

Replacing the National Union Executive Committee, the NCE meets more often than the Convention and prepares reports for its inspection. It includes the Convention's six senior officers and its elected members of the Board.

Notes: * Elected by constituency members via National Convention

+ No elective connection to membership

Source: The Fresh Future, Conservative Party 1998; Conference Guide, BBC News Research Department, 2001

\section{Notes}

1 Quoted in B. Anderson, 'New leader, new voting?', The Spectator, 17 May 1997.

2 D. Finkelstein, 'Why the Conservatives lost', in I. Crewe, B. Gosschalk and B. Bartle (eds), Political Communications (London, Frank Cass, 1998), pp. 12-15.

3 Charter Nerws, April 1989.

4 R. Kelly, 'The whip hand Tory rebels could hold', Parliamentary Brief, February 1995 .

5 P. Whiteley, 'The Conservative campaign', Parliamentary Affairs, 50:4 (1997) 54254.

6 R. Kelly, Conservative Party Conferences: The Hidden System (Manchester, Manchester University Press, 1989).

7 B. Feldman, Report on the Review of the National Union of Conservative and Unionist Associations (London, Conservative Central Office, 1993); N. Fowler, One Party: Reforming The Conservative Party Organisation (London, Conservative Central Office, 1993).

8 R. Kelly, 'Choosing Tory leaders: time to trust the party?', Politics Review, 6:1 (1996) 8-11.

9 Charter News, October 1997.

10 P. Webb and D. Farrell, 'Party members and ideological change', in G. Evans and P. Norris (eds), Critical Elections (London, Sage, 1999), p. 48. 
11 J. Holroyd-Doveton, Young Conservatives (Durham, Pentland Press, 1996); P. Whiteley, P. Seyd and J. Richardson, True Blues (Oxford, Oxford University Press, 1994), p. 202.

12 D. Denver and G. Hands, 'Constituency campaigning', Parliamentary Affairs, 45:4 (1992) 528-44.

13 Whiteley et al., True Blues, p. 207.

14 E. Shaw, The Labour Party since 1979 (London, Routledge, 1994), pp. 4-29.

15 P. Gould, The Unfinished Revolution (London, Little Brown, 1998), pp. 104-87.

16 Conversation with the author, Manchester, 18 May 1998.

17 W. Hague, A Fresh Future for the Conservative Party (London: Conservative Party, 1997).

18 D. Wastell, 'Hague to ballot Tories on reforms', Daily Telegraph, 20 July 1997.

19 Charter Nerws, October 1998.

20 Whiteley et al., True Blues, p. 171.

21 Author's conversation with 'Progress Trust' MPs, Westminster, 15 December 1998.

22 Comments at 'Progress Trust' meeting.

23 S. Driver and L. Martell, New Labour (Oxford, Polity Press, 1998), p. 9.

24. Conversation with the author, Manchester, 27 September 2000.

25 The Fresh Future (London, Conservative Central Office, 1998), p. 32.

26 See P. Kellner, 'Democratic change that has turned Hague into a dictator', London Evening Standard, 17 February 1998.

27 Gould, The Unfinished Revolution, pp. 215-22.

28 The Fresh Future, p. 30.

29 R. Heffernan and M. Marqusee, Defeat from the Jaws of Victory (London, Verso, 1992), pp. 261-301.

30 The Fresh Future, p. 31.

31 A. Norman, 'Power to party members', The House Magazine (1998).

32 R. Shrimsley, 'Tory chief forced out over £3 million cutback', Daily Telegraph, 17 July 1998.

33 Conversation with the author, Manchester, 4 December 1998.

34 C. Challen, The Price of Power. The Secret Funding of the Tory Party (London, Vision, 1998).

35 Charter Newe, March 1999.

36 Conference Guide 2001 (London, BBC News Analysis and Research, 2001), p. 86.

37 J. Lees-Marshment, The Political Marketing of British Political Parties (Manchester, Manchester University Press, 2001), p. 213.

38 Charter Newe, March 2000.

39 P. Buscombe, 'Sometimes it's hard to be a Tory woman', The Spectator, 1 September 2001.

40 S. Walters, Tory Wars. Conservatives in Crisis (London, Politico's, 2001).

41 Author's conversation with James Walsh, Director, Conservative Policy Forum, 2 July 2000.

42 Listening to Britain: A Report (London, Conservative Party, 1999), pp. 2 and 12; The Common Sense Revolution (London, Conservative Party, 1999); conversation with James Walsh.

43 R. Kelly, 'The party conference', in A. Seldon and S. Ball (eds), Conservative Century (Oxford, Oxford University Press, 1994), pp. 221-60.

44 Lees-Marshment, The Political Marketing of British Political Parties.

45 G. Jones, 'MPs face the fury of Tory faithful', Daily Telegraph, 9 October 1997.

46 R. Kelly, 'Farewell conference, hello forum', Political Quarterly, 72:3 (2001) 329-34.

47 R. Kelly, 'Selecting party candidates', Talking Politics, 12:1 (1999). 
48 P. Norris and J. Lovenduski, Political Recruitment (Cambridge, Cambridge University Press, 1995), pp. 65-69.

49 See Daily Telegraph letters page, 12 July 2001.

50 B. Brogan, 'Confused Tories dislike Clarke but expect him to win', Daily Telegraph, 23 July 2001.

51 N. Watt, 'A sleepwalk into unmitigated disaster', Guardian, 20 July 2001.

52 G. Jones, 'Portillo's dream shattered', Daily Telegraph, 18 July 2001.

53 Author's interviews, Liverpool, 15 July 2001.

54. Whiteley et al., True Blues, p. 25, put membership at about 750,000.

55 M. Bentham, 'So just who are these people?', Sunday Telegraph, 19 August 2001.

56 'Undemocratic Tories', Daily Telegraph leader column, 1 August 2001.

57 D. Cracknell, 'Poll shows Europe is the main issue for Conservatives', Sunday Telegraph, 26 August 2001.

58 Letter to author from Stephen Phillips, CCO Director of Operations and Conferences, 18 October 2001.

59 R. Punnett, Selecting the Party Leader (Hemel Hempstead, Harvester Wheatsheaf, 1992), pp. 117-22.

60 A. Grice, 'Activists demand sweeping changes to rules on electing party leader', Independent, 9 October 2001.

61 Conversation with the author, London, 9 June 2001.

62 P. Seyd and P. Whiteley, Labour's Grass Roots (Oxford, Clarendon Press, 1992), p. 188; P. Seyd and P. Whiteley, 'Why Blair needs his grass roots', New Statesman, 6 December 1999.

63 J. Lees-Marshment and S. Quayle, 'Empowering the members or marketing the party? The Conservative reforms of 1998', Political Quarterly, 72:2 (2001) 204-12. 